\title{
Appropriate, Adapt, Inhabit: The Recreation of Public Space in the Republic of Georgia
}

\author{
THOMAS IBRAHIM \\ Arizona State University
}

\author{
CLAUDIO VEKSTEIN \\ Arizona State University
}

\begin{abstract}
The collapse of the Soviet Union marked the beginning of the difficult deconstruction of the regime and ideology which controlled the East for the majority of the 20th Century. In the Republic of Georgia, Soviet collapse catalyzed a series of ethnically prompted conflicts and civil war which prevented the unification of the country under a national agenda, thus creating fertile ground for corruption, privatization and sale of public space. The earliest example of the corrupt transfer of property was the sale of the former Palace of Rituals, in Tbilisi, to Georgian oligarch Badri Patarkatsishvili, which is still primarily used as a private residence by his family. After the Rose Revolution in 2003, Georgia faced rapid institutional reforms under President Mikheil Saakashvili, who legitimized his regime by unifying regions that continuously identified as Georgian (excluding territories Abkhazia and S. Ossetia), collecting revenues via taxation, and attracting the foreign investment that Georgia desperately needed.
\end{abstract}

The national project of the Saakashvili government was the rapid creation of the image of a westernized, contemporary state, with the aim of earning European Union membership. New stability coupled with laissez-faire policy towards foreign investment and development accelerated privatization of public buildings and the erosion of urban space in the capital city, Tbilisi, and across the country. Furthermore, the regime's approach to public and infrastructural projects were a manifestation of the arbitrary adoption of western values, while ignoring the existing Georgian urban and architectural context and identity. Former Soviet public buildings were (and continue to be) auctioned, and their demolition or retention are left completely up to the discretion of the new owners. One of the most extreme cases of destruction of public space was the near razing of the National Scientific Library, which holds some of the earliest printed books in the Georgian language, and is one of only three libraries in Tbilisi. The association of public buildings with the Soviet regime is used as the premise for their privatization and destruction, which in turn further alienates Georgians by eliminating much needed public institutional buildings.

There are several social issues remaining in Georgia, including ethnic discrimination lingering from the early post-Soviet period, and the issue of internally displaced persons (IDPs) who live in extreme poverty in former Soviet public buildings. In Tbilisi, these issues are most evident in the former Industrial Pedagogical Technicum complex, which embodies the depth to which the Georgian government addressed pertinent local issues. The building is currently occupied by approximately sixty (60) refugee families remaining from the GeorgianAbkhazian conflict and the Russo-Georgian war, who are living in separation because of ethnic friction. Though the complex is largely dilapidated, key buildings present opportunities for focal interventions which could house much-needed public functions for its inhabitants, while integrating the small communities within the building into the city. The appropriation, adaptation, and inhabitation of this significant Late-Soviet structure by the public and for the public good, presents the opportunity for changes that could be re-foundational for Georgia and prevent further cultural erosion.

\section{INTRODUCTION}

According to the ancient myth, Icarus, a boy who escapes captivity through flight, is consumed by ambition, and despite warning to avoid the blazing sun, he ascends until the feather and wax wings created by his father are irreversibly damaged, plunging him to the depths of the sea. ${ }^{1}$ The myth of Icarus is somehow consonant not only with the story of the Soviet collapse, of the inevitable plunge following ambitious idealism but most recently, in Tbilisi, has been dramatically manifested in the late destruction of the relief sculpture affixed to the façade of the former Industrial Pedagogical Technicum. The dismantling of the new Soviet man, a neo-Vitruvian figure with bat-like wings as the emerging archetype, irrespective of the country's cultural, ethnic, and linguistic diversity, embodies the fall of idealism, of Trotsky's hyper-ideological superman. ${ }^{2}$ This fateful fall may be a necessary step towards the acceptance, inhabitation, and humanization of former Soviet structures, a fruitful synergy between the dismantling, and potential re-appropriation of past identities.

\section{THE COMPLEX INDEPENDENCE AND UNITY OF GEORGIA: THE ORIGINS OF THE 200,000 INTERNALLY DISPLACED PERSONS}

When the Russian empire fell to the Bolsheviks, Georgian intelligentsia seized the opportunity to declare independence in May of 1918, and attempted to unify with the regions of Abkhazia and South Ossetia. Before unification could be achieved, the fledgling Democratic Republic of Georgia, was taken. On February 25, 1921, "'the red banner of the Soviet power [flew] above Tbilisi'... [marking] the beginning of the country's revival," " despite Georgia's First Chairman Noe Zhordania's plea to the West for protection. Amidst the collapse of the Soviet Union, Georgia again declared independence in the March of 1990, but independence 


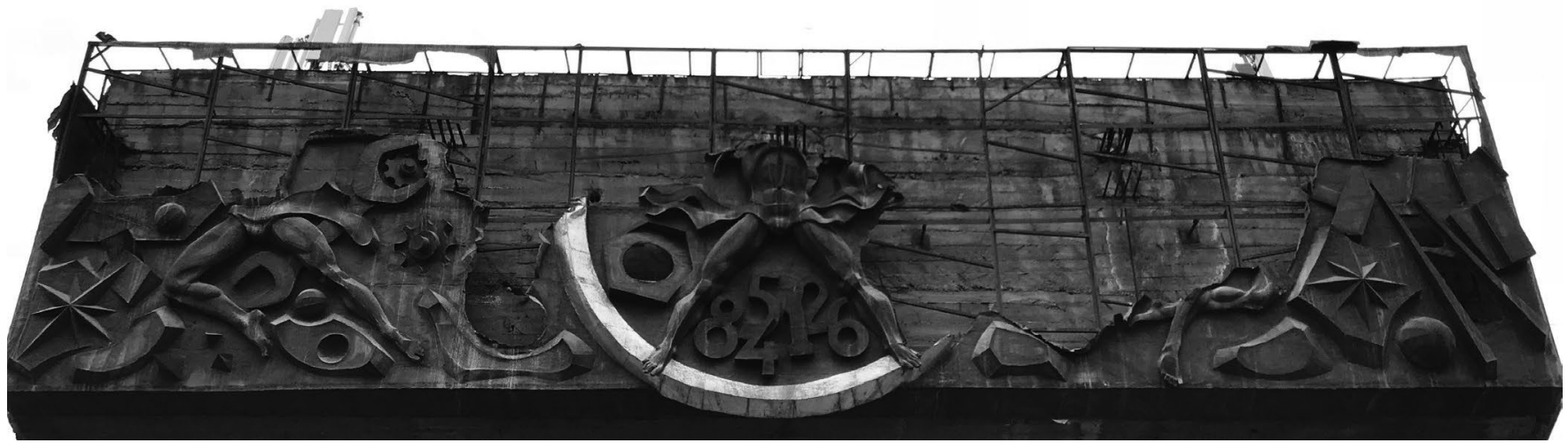

Figure 1: Relief Sculpture on Technicum Theater Facade after continued theft of material, July 2018, Thomas Ibrahim.

was again accompanied with challenges of unification, and establishing a secure state in a complex geo-political atmosphere. As was the case in several ex-communist countries, nationalism became "a way for the ex-communist nomenklatura to survive;" " Georgia's leadership attempted to maintain power via nationalism which served to marginalize minorities, and further alienate the regions of Abkhazia and South Ossetia. When the Georgian Supreme Soviet split from the Soviet Union with a declaration that Georgia was an annexed and occupied state, Abkhazia proceeded by declaring independence from Georgia and petitioning to Moscow to be incorporated within the crumpling Soviet Union.

In addition to the conflicts with Abkhazia and South Ossetia, Georgia entered another internal conflict, which began with the deposition of the nation's first president, Zviad Gamsakhurdia, in the January of 1992. Gamsakhurdia was forced to flee to Armenia, and Tbilisi fell under the control of Eduard Shevardnadze; however, Gamsakhurdia, of Megrelian descent, maintained support from his region in Western Georgia, and some international recognition as the legitimate president of Georgia. As a part of the power struggle between the two leaders, the race to gain control over Abkhazia led Eduard Shevardnadze to send a paramilitary group known as the Mkhedrioni (meaning "knights") to the region. ${ }^{5}$ The Mkhedrioni, much like the forces of Gamsakhurdia, held onto the same ethnic exclusivist attitude to legitimize atrocities against ethnic Abkhazians. With Russian logistical support, Abkhazia managed to win the war against Georgia in the Autumn of 1993, and approximately 200,000 ethnic Georgians where ousted from the region, most of which migrated to the adjacent Samegrelo-Zemo Svaneti region and the Georgian capital city, Tbilisi. ${ }^{6}$ Since 1993, all diplomatic attempts to unify the two nations have failed, and both Abkhazia and South Ossetia are "frozen conflict" zones.

\section{THE INDUSTRIAL PEDAGOGICAL TECHNICUM}

Sitting in a marshrutka (mini bus) after a long journey from western Georgia, entering Tbilisi, travelers are met by a peculiar figure. Through the dense vegetation, a massive sculpture of a man with his arms and legs outstretched in liberation, head facing the heavens, and golden bat-like wings, his most iconic feature. For nearly four decades the legendary neo-Vitruvian man stood in the midst of nude male and female figures, an allusion to the new Soviet man and a new Adam and Eve, haunting children and adults alike with his intimidating aura. Scattered across the massive sculpture, planetary bodies, numbers, a ladder, bolts, and gears - completely abstract, but obviously defining an epoch of industrialization that elevates the human spirit to heights never before reached. The relief sculpture affixed to the façade of the former Industrial Pedagogical Technicum theater, was rumored to have been created by the famous, and controversial, Georgian sculptor Zurab Tsereteli, ${ }^{8}$ but was likely completed by apprentices in his workshop because of its anonymity and the fact that Tsereteli does not have the sculpture listed in his publications or portfolio. Surprisingly, in February of 2018, the man's wings were taken, and then in March, nearly the rest of his body and other major components of the sculpture, as a consequence of an apparently irremediable process.

The Technicum complex, designed by Georgian architect Nikolaz Lasareishvili, part of an ensemble of monumental architecture, was completed in the same decade as the adjacent former Ministry of Transportation Building, now the Bank of Georgia Headquarters, and the current Fortuna FM Radio Building, in 1978. The building complex is massive, built on a mountain, and currently sheathed in dense vegetation. Before the Late-Soviet period, a public institutional construction of this magnitude would never have been built into a rugged landscape. The complex is comprised of a total of five buildings: 1 ) a main block that originally housed classrooms, a library, and lobby, 2) the theater/lecture hall building which has the sculpture attached to its cantilevered façade, and a large terrace, 3) an industrial teaching facility housing equipment, 4) a bridge that connects the main block to the industrial facilities, and finally 5) a building that is separated from the others, farther uphill, that was used as student dormitories. The building is site-specific; standing on 


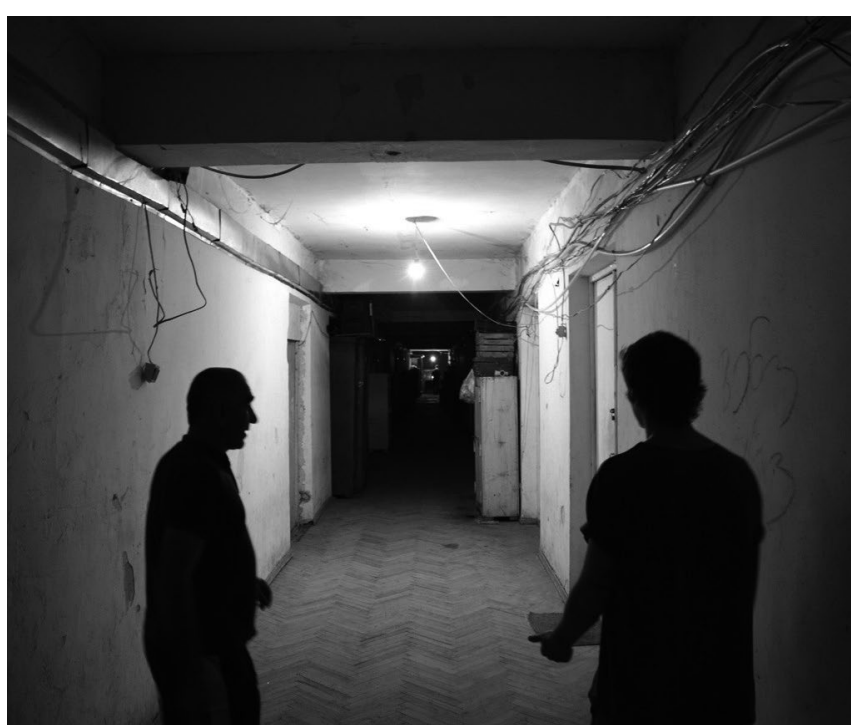

Figure 2: Industrial Technicum Main Building Interior, now housing of Internally Displaced Persons from the Georgian Civil War and the RussoGeorgian War, June 2017, Thomas Ibrahim.

the terrace, beneath the cantilevering theater, the adjacent hills are on the same level. The form, volumetric relationship of the exterior and interior, and fenestration of the theater are undoubtedly rooted in Russian Constructivism; it is likely inspired by The Rusakov Worker's Club by Konstantin Melnikov, but maintains a unique character. The building also demonstrates an awareness of a breach in the so-called Iron Curtain, as the typology is reminiscent of the works of Le Corbusier and South American Modernists, like Affonso Reidy.

\section{SOVIET PUBLIC ARCHITECTURE POST-SOVIET COLLAPSE AND THE CASE OF THE FORMER INDUSTRIAL TECHNICUM}

After the Georgian-Abkhazian war, ethnic Georgians were expelled from Abkhazia and in need of refuge, tens of thousands of people traversed the entire country to arrive in Tbilisi. Without choice, these internally displaced persons (IDPs) occupied former Soviet public buildings, schools, and hotels. The most notable urban squat was in the center of the city in the iconic Iveria Hotel. Considering the building's location and the image that it presented, when Mikheil Saakashvili was elected president, one of his first actions was to vacate the hotel, with the intention of its demolition to make way for a new western-style hotel. With a plea from the architect Otar Kalandarishvili's family, the skeleton of the building was saved, but the balconies which originally wrapped the entire building were sheathed in a glass curtain wall: it was fated to become the Radisson Blu Iveria. ${ }^{9}$ It was not only the Iveria Hotel that lost its original qualities, Saakashvili took initiative to remove several Soviet symbols across the city, ${ }_{10}$ including the famous Soviet monument known colloquially as Andropov's Ears, which was located in the former Republic Square, adjacent to the Iveria.
In the case of the Industrial Pedagogical Technicum, the Soviet Industrial Ministry was defunct, and the building no longer had a purpose. IDPs began partitioning parts of the building and creating an informal living condition within. The site-specificity and monumentality which characterized the complex would become perfect conditions for their further alienation. Since the building is not centrally located, accommodating for the Georgians living in the Technicum did not take precedence during the Saakashvili regime. Furthermore, the inhabitants were actually threatened with potential eviction since they have not been granted ownership of the building. The policy towards state property under Saakashvili's government, was similar to previous regimes: "selling everything but our conscience."

The attitude of discarding and privatizing significant Soviet architectural landmarks across the city, began with the aforementioned sale of the Palace of Rituals to Badri Patarkatsishvili. The Palace's muralist once stated in an interview, "it was a crime to sell this building, taking away the feeling of festivity from the youth and the public generally provided by the interior... [Patarkatsishvili] purchased whatever was offered for sale, but the one who sold it is a criminal." He also states that the building was still in use by the public at the time that it was sold. ${ }^{11}$

After the Russo-Georgian War in 2008, there were more refugees seeking shelter who migrated to Tbilisi. They came to the Technicum, and began inhabiting the building alongside the Georgians from Abkhazia. The two parties built a partition along the fourth and fifth floors of the main block building, enter from opposite sides, and when interviewed, spoke ill of each other because of the aforementioned residual ethnic tension. The refugees displaced in 2008 maintain that the inhabitants from Abkhazia are more financially stable but are living in the building waiting to receive a government handout when the building is sold. On the other side of the wall, the same sentiments were shared. On both sides of the border, inhabitants are burning wood for warmth, from trees cut down on the premises. The wood is stored in the makeshift common areas and can be seen through the windows as soon as the Autumn cold covers Tbilisi. The inhabitants would prefer to run gas lines in the building, but have been forbidden from doing such by the government because the building is not privatized in their name. The original toilets from the Technicum are shared by entire floors of inhabitants, and some additional ones have been added in a few of the makeshift units - some toilets placed directly off the hallway. Wastewater is run through pipes that are punched out of the building's back façade. Altogether the building is inhabited by approximately sixty (60) families, but some new units have appeared between the Summer of 2016 and the Summer of 2017. When asked how they felt about living in the building, answers were mixed. There were several remarks of admiration of the integrity of the construction, 


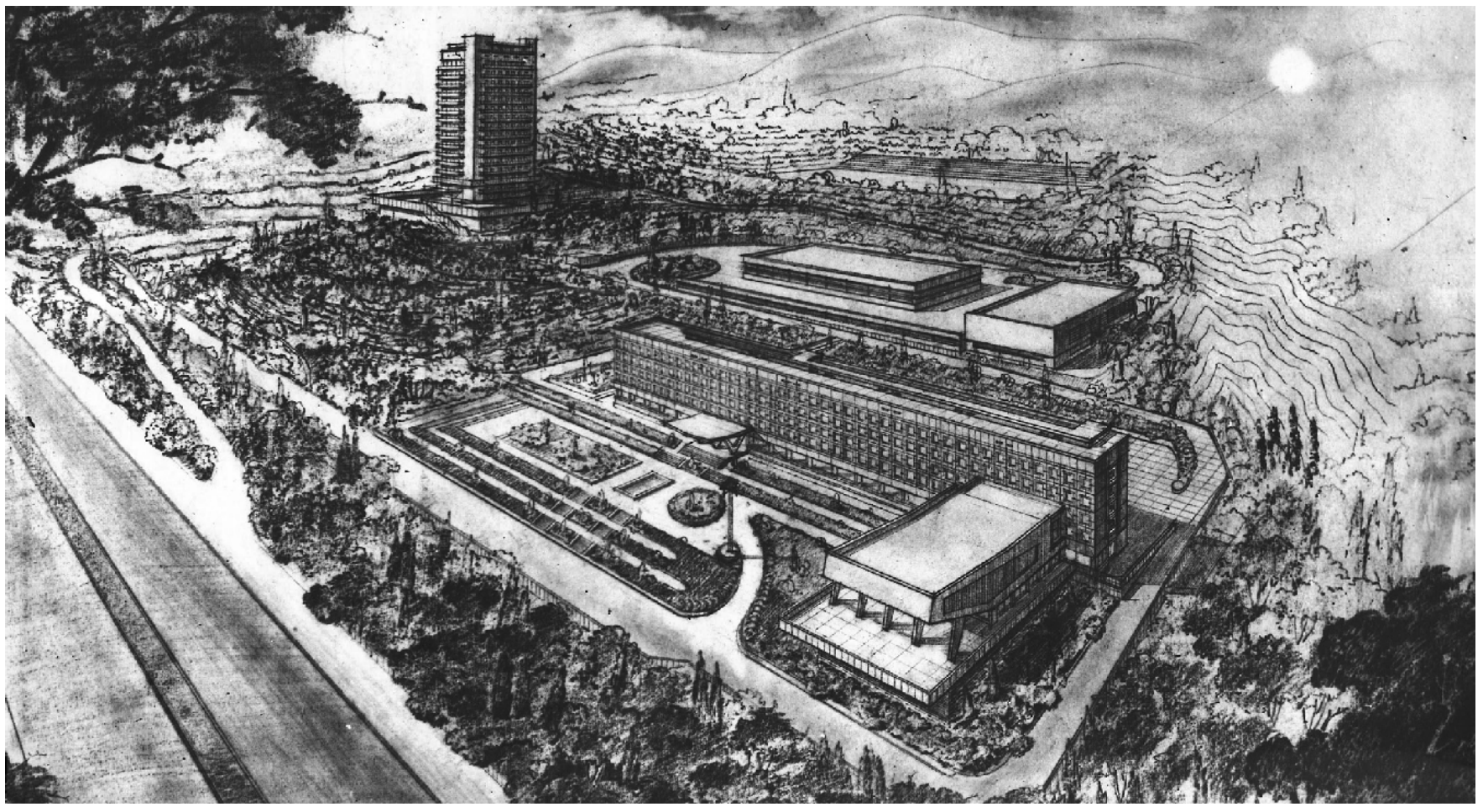

Figure 3: Industrial Pedagogical Technicum, Bird's-Eyeview Perspective Drawing of the entire building complex, image courtesy of Architect Nikolaz Lasareishvili Family.

but certainly, everyone agreed that the conditions in the building were far below any acceptable standard. However, the communal qualities of living in the building are the little solace that come with hardship. In addition to the building's inhabitants, there are an additional two parties occupying the main block building, an elementary school located on the first level of the building on the northern side, and Icarus Tourism College. The elementary school's premises are under the ownership of Tbilisi City Hall, and it was placed in the building to accommodate for the inhabitant's children, as well as children from the neighboring community in the Dighomi district. Icarus is leasing the southern side of the first through third floors of the same building from the Georgian Ministry of Economy, the organization which presides over all obsolete state property.

\section{CONTRIBUTORS TO DESTRUCTION: POLITICS OF THE SEEMINGLY OBSOLETE}

There are several threats to the former Industrial Pedagogical Technicum complex, beginning with its Soviet-ness; Modern building's association with the imposed, foreign totalitarian regime is used as the main premise for sale and destruction. The second threat to the Technicum, is the complexity of the politics surrounding the ownership of the building, its inhabitants, and potential investors (both those wanting to capitalize on the Technicum's unique industrial history and those wanting to raze and redevelop the real estate). The final threat to the Technicum is scavengers who are still visiting the building and removing steel railings and industrial equipment to sell in the local market.

The Technicum's inhabitants claim that the complex, like several other public buildings, was nearly sold to investors twice during the Saakashvili regime. The fear of eviction without compensation would leave the inhabitants homeless, and is not unfounded. From our first few interactions with the Georgian Ministry of Economy via the National Agency of State Property, in June and July of 2017, we were asked multiple times, with excitement, if I was going to purchase the building complex. When I explained that I was interested in using the theater for a cultural event, they said that there was no precedence for such a use of state property; it would have taken less effort to purchase a public building than to use it for a cultural event. It was only after a series of meetings with the heads of the National Agency of State Property that we were granted the permissions to use the Technicum theater.

On September 30, 2017, we noticed that some interior walls in the theater which were discontinuous with the inhabitants living quarters were demolished, and on November 4, we found that the cladding on the terrace of the same building was removed. The interest of the Georgian government to sell the building or real estate, Icarus Tourism School's interest in privatizing the building in their favor, and the interest of the IDP's to maintain shelter, and the failure of any of these parties to communicate, leads to further destruction of the 
Technicum. Additionally, in late October, during a visit to the building, we witnessed two men removing steel railings and window framing from the theater. When asked why they were removing the materials, and after expressing that they were stealing state property, they casually and indifferently replied that they were going to sell the materials and that the state did not care about the building any longer.

\section{A NEW ATTITUDE: IDENTITY, IDEOLOGY, INHABIT!}

The present circumstances surrounding the former Industrial Pedagogical Technicum within the historical and present context can be portrayed as follows. While the city disavows the existence of the building because of its location on the periphery, distanced by its monumental placement and concealed in dense vegetation, the building simultaneously negates to identify with the city, given its foreign communist origins, which reject the local identity through ideological symbolism, causing the building to fall under the present conditions of dilapidation and neglect. Furthermore, the building is occupied by two ethnic identities that refuse each other, while the government ignores them both, because of ethnicity in one case, but more generally out of mere dereliction. The Technicum negates itself currently because it no longer holds its original identity, which was lost with the collapse of the Soviet Union, and furthered recently with the loss of the relief sculpture on its façade, the last trace of its cultural and ideological identity. The situation is excessively chaotic - nearly void. The question then becomes how identity can arise from almost completely depleted conditions? Identity is typically concerned with itself, and this is seen in Georgia immediately following the Soviet collapse, through the actions of the ethno-nationalists, in the attempted elimination of an abstract "other." Another way to find identity, in void, is to adopt a new identity, which was the established national agenda during the Saakashvili regime. The first way that it ought to happen is more Hegelian, that is surpassing the contradiction: instead of simply "I am Georgian, but not Soviet," then "I am Georgian while also something else," identity should not be exclusive. ${ }^{12}$ That is to say, Georgian identity is not contingent on the Soviet, but that because Georgia was Soviet, Soviet-ness remains a part of the Georgian identity, heritage, and history, resulting in an identity that is neither Georgian nor Soviet. Meaning that Georgian identity, like any other identity can not be a pure identity, purity being the mere reflection of self, but rather a complex mixture of historical and cultural elements compounded over millennia. The history of Georgia after the 12th Century is that of a country and people who were conquered and fragmented because of the control of several empires until the annexation by Russia and incorporation into the Soviet Union, ${ }^{13}$ and that complex history cannot be eradicated. And the presence of the other, the foreign, allows for an awareness of self, which is the foundation of identity. When history is erased, autocracy and the exploitation of the Georgian people by tyrants, and even an ironic nostalgia for the Soviet regime is perpetuated, as has been the case since the inception of Georgian independence.

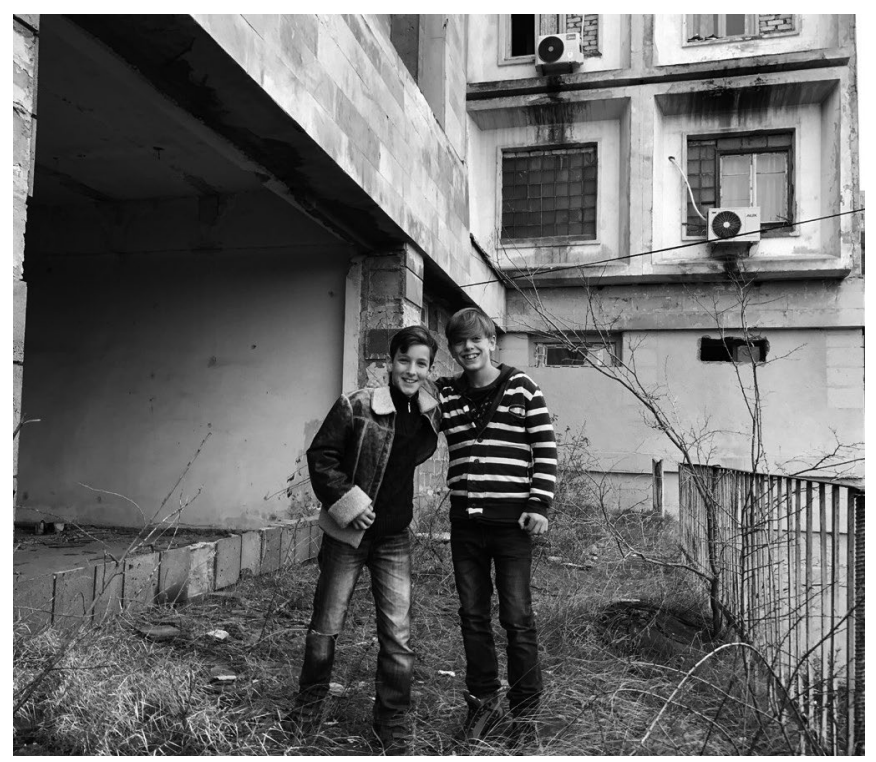

Figure 4: Elementary School Students during a break climbing on the abandoned Technicum terrace, October 2017, Thomas Ibrahim.

Our response to the current situation surrounding the former Technicum is that of a critical realism, an attitude that starts from accepting the situation as it is, but is not passive, and better prepares to act and address it accordingly, with positive pragmatism. It is not merely the use of common sense to inhabit, or adaptively reuse buildings because they exist or because of their present occupation. To further "Inhabit!" the building is not merely a pragmatic solution, it is a critical ambition to challenge the present conditions; it is a big positive step through negating the previously mentioned denials - to challenge and contest the existing reality. The rebuilding and westernization which took place under Saakashvili, is not Georgian in nature per se, despite the fact that it is now a part of Georgian contemporary history and the urban environment. It can be simply described as neoliberal or abstractly western - an attempt to erase the Soviet identity without critically negating (or addressing) it, and without offering any alternative or authentic way to Georgian identity. While blindly erasing Soviet identity, the Georgian is also abstractly eliminated, perpetuating extreme conservative and fundamentalist ideologies. Furthermore, ideological symbolism does not supersede reality, if that approach was feasible then the Soviet Union would have never dissolved. 
Perhaps the initial fascination to the former Technicum stemmed from the lure of the relief sculpture on theater façade - ideology manifested in art led to an unveiling of a dismal situation. The sudden and shameful disappearance of the sculpture strips the scene of beauty, but confronts us with the cruelty of the conditions at their core. It may well illustrate, in this case, a first act in a movement towards something more substantive than the placement of ideological symbols by a distant authority - the act of ironically unintended deconstruction of illusory identities and ideologies.

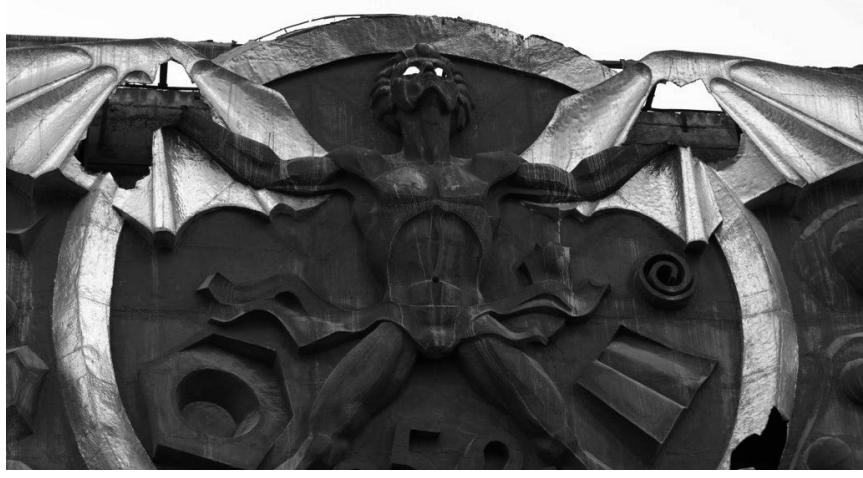

Figure 5: Neo-Vitruvian Sculpture on the Facade of the Technicum before destruction, June 2017, Thomas Ibrahim.

The first steps of inhabitation are occupying and dismantling a necessary act of appropriation. To inhabit! means more than coming in and re-using a building, it is also the reimagining of its identity; the fall of the relief sculpture is not the fall of the building, but the fall of outstanding aesthetic idealism. We are not suggesting that the immediate reuse of this building (or others) will resolve the national issues in Georgia, but that it is a necessary step in confronting past idealism. If the building is finally demolished or if existing symbols are replaced with more contemporary ones, it would not be truly critical to the identity. The phenomenal icons from the past regime, which we certainly wish to be protected (for artistic and historical reasons) should not, however, necessarily be left untouched as they somehow legitimize the idealism they audaciously represented. In its present condition, with the sculpture being crudely dismantled and sold for its material weight, the building has lost its aura, authority, and distance - meaning its unapproachable monumentality, its presence as "the house of the people" to be seen by the masses from afar.

A new Inhabit! attitude will be fulfilled when these structures finally become simultaneously public and intimate, and when they truly live up to the ideals of the past without pretension. In the case of the Industrial Pedagogical Technicum, built with noble public intention and predicated on artistic but monumental and ideological expression, the observed fall of Icarus, may further strengthen the dwelling potential of the Technicum, while reconciling it with Tbilisi's urban fabric, embedding it in the local communities to house a renewal of public space and social spirit.

\section{ENDNOTES}

1. Peabody, Josephine Preston, translator. "Icarus and Daedalus." CommonLit, Original Published 1897.

2. Leon Trotsky wrote in 1924 in Literature and Revolution about the "Communist man," about a "man of the future," a "man [who] will make it his purpose to master his own feelings, to raise his instincts to the heights of consciousness, to thereby to raise himself to a new plane, to create a higher social biologic type, or, if you please, a superman."

3. Chiaushreli, V. et al. Sunny Georgia. Rustaveli Prospect, n.d, pp. 24-26.

4. Žižek, Slavoj. "Slavoj Žižek: Nationalism Is a Way for Communists to Survive in Ex-Communist European Countries." 10 Dec. 2017. Accessed 24 Mar. 2018.

5. Zürcher, Christoph. "Georgia's Time of Troubles, 1989-1993." Statehood and Security: Georgia after the Rose Revolution, edited by Bruno Coppieters and Robert Legvold, MIT Press, 2005, pp. 83-115.

6. Ministry of Internally Displaced Persons from the Occupied Territories, Accommodation and Refugees of Georgia. "Number of Registered IDPs- Statistics Occupied Territories, Accommodation and Refugees of Georgia, 17 Sept. 2014.

7. Nodia, Ghia. "Georgia: Dimensions of Insecurity." Statehood and Security: Georgia after the Rose Revolution, edited by Bruno Coppieters and Robert Legvold, MIT Press, 2005, pp. 39-82.

8. Ibrahim, Thomas, and Lasha Mindiashvili. "Architect Nikolaz Lasareishvili Family Interview." 11 July 2017.

9. Warsza, Joanna, and Nini Palavandishvili, editors. "We Started with the Forest, the Hole and the Octupus." Ministry of Highways: a Guide to the Performative Architecture of Tbilisi, by Nini Palavandishvili, The Other Space Foundation, 2011 pp. 41-48.

10. Lappartient, Vincent, et al. New Georgia: Georgian Architecture after the Rose Revolution 2004-2012. Ministry of Culture and Monument Protection of Georgia, 2012

11. Bostanashvili, Shota and David Bostanashvili. Butza: Architect Victor Djorbenadze. pp. 128-129, 167-169. Georgian Technical Universiy, 2012.

12. Adorno, Theodor W., and E. B. Ashton. Negative Dialectics. Seabury Press, 1973.

13. King, Charles. The Ghost of Freedom: a History of the Caucasus. Oxford University Press, 2012

14. Antidze, Margarita. "Exclusive: Trump Pulled out of Project in Ex-Soviet Georgia to Avoid Conflict of Interest - Ex Partner," Reuters, Thomson Reuters, 10 Jan. 2017

15. Chaubin, Frédéric. CCCP: Cosmic Communist Constructions Photographed. Taschen, 2014

16. Ibrahim, Thomas, and Irakli Zhvania. "Tbilisi After Saakashvili, The Georgian Dream Party, and Neoliberalism: Interview with Urban Planner Irakli Zhvania." 6 July 2017.

17. Khutsishvili, George. "Intervention in Transcaucuses" Boston University, Institute for the Study of Conflict, Ideology, and Policy, Feb.- Mar. 1994.

18. Nodia, Ghia. "Nationalism Can Be Beneficial." Nationalism and Ethnic Conflict, by Charles P. Cozic, Greenhaven Press, 1994, pp. 34-41.

19. Salukvadze, Joseph, and Oleg Golubchikov. "City as a Geopolitics: Tbilisi, Georgia - A Globalizing Metropolis in a Turbulent Region." Cities, vol. 52, 12 Dec. 2015, pp. 39-54. Elsevier, doi:10.1016/j.cities.2015.11.013.

20. "Urbanists, Architects to Reimagine Soviet-Era Buildings in Tbilisi." Agenda.ge, 15 Nov. 2017. 